\title{
På A. D. Jørgensens 100 års dag i Gråsten 11. 6. 1940.
}

\section{Af H. Lausten-Thomsen.}

A. D. Jørgensen slutter hovedafsnittet $i \sin " R$ e degørelse for min udvikling og mit forfatters $k$ a bi med at sige:

"Det er mig såre lidet at vejes eller vrages som "historiker", når jeg kun tør gøre regning på, at danske mænd og kvinder vil genkende mig som en af deres egne, at jeg af og til vil blive nælvnt blandt dem, som i tunge Tider aldrig mistvivlede om vor frelse.« I dag er vi samlet for at nævne ham som én af de bedste af disse, for at hædre hans minde og at lade det hjælpe os til at holde mistilliden til vor frelse nede eller helst ganske borte. Tunge tider rammer slagtled efter slagtled, det er mennesker som A. D. Jorgensen, der hjælper til at $\mathrm{t}$ å l e dem, ikke til at bær e dem, men til at vedligeholde det faste håb og støtte sig til "den lidenskabelige kærlighed til folk og fædreland«, som A. D. Jørgensen og mange af os fik $i$ arv fra vore hjem, "ikke den kærlighed, 
som er en ild, men den, som er et instinkt, en længsel og en dyb lykke«.

A. D. Jørgensens »Fyrretyve fortællinger af f ædrelandets historie« var udkommet 1882 og var i højere mon end tidligere nogen bog med lignende emner blevet folkelæsning i Sønderjylland. Sprogforeningen havde uddelt den i titusindvis, og mit slægtled i Nordslesvig fik den tidligt $i$ hænde. Selv om jeg ikke helt forstod den dybe mening $i$ hans fortælling om Hadding ved den port, hvor »døden var overvunden og livets evne uden ende", selv om jeg og andre unge tit læste hans fortælling som spændende eventyr, så var han med til at præge os. Så var det mere end nogen anden ham, der vakte vor historiske sans og forståelse, så blev A. D. Jørgensen tidligt vor læremester, og den første bog, jeg - fraset skolebøger - selv fik lov at købe, var første bind af hans »F or t æ ll inger a f Nordens H is torie«, udkommet 1892, og jeg glemmer aldrig den levende opdagelsesglæde, hvormed jeg læste om "Sæmund Frode og den hellige biskop Ion", selv om jeg da heller ikke endnu fattede betydningen af vekselvirkningen mellem nordisk og fremmed, at man aldrig må tabe sig selv og sit eget, men at der kan gives det hjemlige oget værd ved kendskab til og i skæret af fremmed visdom.

Da denne bog udkom, havde jeg lyttet til A. D. Jørgenser ved et møde $\mathrm{i}$ Kolding, hørt lans rolige tale og havde oplevet hans milde og myndige væsen i venners kreds, når hans klare kritik kunde ledsages af et smil, der lyste helt op i det skønne, rene ansigt. Naturligvis mødtes han, når han to gange om året talte i højskolekredsen i Kolding, af ærbødighed, man var stolt af at have den grundigste kender og kyndigste gransker af vort lands historie som ordfører, men især var han omgivet af tillid.

Det er naturligvis kun en ganske ung mands indtryk, jeg kan gengive, men dem kan jeg samle i ordene: modig sanddruhed og myndig og klog mildhed. A. D. Jørgensen havde den gang største delen af sit virke bag sig. Som historiker 
havde han banet nye veje, havde ryddet grund, hvorpå andre kunde bygge, havde givet yderst værdifulde bidrag til Sønderjyllands, til Danmarks og Nordens historie, og var han nået til ny opfattelse, fremsatte han den åbent og stærkt, De, der hørte hans foredrag om "Kong Kristian VIII. og den danske sagi Nordslesvig«, som han holdt ved folkehøjskolens 50 års jubilæum den 8. sept. 1894 i Skibelund krat, og hvorved han ganske forandrede den tids opfattelse af Kr. VIII.s nationale stilling, glemmer næppe, hvor stærkt et indtryk, han gjorde ved at kæde ny oplysninger til gamle kendsgerninger, hvorledes han på en gang søgte retfærdighed og at se udviklingen i åndens lys.

Undertiden kunde A. D. Jørgensen synes unødig skarp over for gamle opfattelser, det var sandheden, han sogte, sandheden om vort lands fortid, om vort folks bedrifter, en sandhed, så stærk og stolt, at den ikke trænger til at smykkes med uægte flitter og romantiske gætninger. Af denne sandhedstrang var hans videnskabelige kritik, hans granskerarbejde, hans myndighed vokset. Ud af den havde han fort ny synspunkter frem i dansk historie, havde skabt sine historiske værker: "Den nordiske kirkes grundlæggelse og første udvikling“, som H a n O lrik kaldte hans ypperste værk, bøgerne om $\mathrm{Z}$ o ëga, Hans Adolf Brorsen, Niels Steensen, Johannes Ewald og Peter Griffenfeld og var ifærd med at skrive VI. bind af \#Danmarks riges historie«, hans sidste ufuldførte værk.

Det kunde ikke undgås, at han mødte modstand, når han nedbrød gamle og tilvante forestillinger, men det ligger uden for enhver tvivl, at "vor første historiker«, som professor E r sl e v har kaldt ham, băde har gjort vor historiske viden rigere og sandfærdigere, og som ingen anden har vakt folkets sans for den. Han har banet veje for vor tids granskere; Danmarks første rigsarkivar har gjort det lettere for senere tider at nå frem til historiens kilder, han fremforte granskningens resultater $\mathrm{i}$ arbejder, der i sproglig henseende er bedre end det me- 
ste, der er skrevet på dansk, og som altid viser hans personlighed bag emnet, hans ildhu for historien, hans kærlighed til det arbejde, det blev hans lykkelige lod at udføre i det danske folk. Der var, som P o u 1 B j e r g e udtrykte det, en varme, en klarhed og en grundighed, der forekom mig næsten som ødselhed, over hans historiefortælling, både når han talte ved et folkeligt møde, og når han på tomandshaand gav oplysning fra sin rige viden.

A. D. Jørgensen var fra sin tidlige ungdom optaget af arbejdet for det danske Sønderjylland, og i det 1866 oprettède "Sønderjydsk samfund" var han, så længe, det var til - indtil 1870 - en flittig foredragsholder og medarbejder; til sin død var han den ledende mand i sønderjydske foreninger i København - $4 \mathrm{~S}$ og 2 lover $\rightarrow$, hans venner kaldte ham undertiden spøgefuldt for "Oversønderjyden«. Han var sin videnskab en god mand, han var folkeoplysningen en trofast tjener, han var den ihærdigste og klogeste, når der skulde planlægges noget nyt til gavn for Sønderjyllands danskhed. H. P. H a n ssen var den hjemlige rådgiver i mange forhold, selv søgte han tit råd og støtte hos A. D. Jørgensen, og mange gjorde som han. Poul Bjerge har smukt og følt fortalt om den hjalp og venlighed, han mødte hos rigsarkivaren. At det var ham, der var den egentlige ophavsmand til og redaktør af "Sønderjydske årbøger" og deres flittige medarbejder, er vel kendt. Det er vel derfor, at jeg som formand for »Historisk samfund for Sønderjylland" har den ære at tale her i dag; men det er ikke kun for "Historisk samfund «, jeg har grund til at sige tak og aflægge vidnesbyrd om rigsarkivar A. D. Jørgensen. Det cr også ganske personligt.

I min og mine jævnaldrendes ungdom var det store spørgsmål for hver enkelt af os, om vi skulde udvandre, inden vi fyldte 17 år, eller blive i Sønderjylland med udsigt til at skulle blive prøjsiske soldater. Det var det afgørende sporgsmål, der måtte og skulde tages stilling til - og altid af unge og umodne 
mennersker. Jeg som andre drøftede det med slægt og venner. Samme dag, da A. D. Jørgensen i 1894 havde talt om Kristian VIII. i Skibelund, formanede K l o p p e n b org-S k r u m a g e r mig starkt til at blive; han havde været prøjsisk soldat uden at tage skade. Det kunde gøres. Da faldt det naturligt også at tale med A. D. Jørgensen, den mand, jeg så op til og hałude tillid til som kanske til ingen anden, og jeg mindes endnu med tak den venlighed, den milde klogskab, hvormed han drøftede dette livsvigtige spørgsmål med en ung mand. Da syntes jeg, at jeg så mere af $A$. D. Jørgensens varme og nænsomme vilje til at hjælpe, end jeg ellers har haft lejlighed til det. Som det gik mig, er det nok gảet mange. Havde man lov til en aftenstund sammen med ældre eller med andre unge sønderjyder at flokkes om A. D. Jørgensen og hans nære venner $\mathrm{K}$ a y s e r og K'ruse, så fik man at vide, at der bag den lyse korrekthed gemte sig både et rigt lune og et varmt hjerte. Han var i mange måder sjælen i băde det materielle og aandelige arbejde, der fra kongeriget kunde udføres til støtte for denne landsdels danske kultur.

Sidste gang, jeg traf A. D. Jorgensen, var i højsommeren 1897, han havde talt ved et møde i Vejle, og vi var ene to $i$ jernbanevognen til Fredericia. Jeg skulde sydpå for at dygtiggøre mig til at arbejde $i$ Sønderjylland, og rigsarkivaren talte med mig om mål og midler, om arbejcle, der lå til ungdommen, om gerning, han havde udført, fuld af liv og arbejdslyst. Et par måneder senere var han ikke mere, og intet andet enkelt dødsfald har vel ramt den danske del af Sønderjylland saa hårdt og voldt så $d y$ b en sorg - lige undtagen redaktør J e ss e n s, næppe 9 år senere.

Jessen skrev den gang:

"Mest sørger vi, der i ham så den sønderjyde i kongeriget, hvis liv næst efter Hans Majestæt Kongens havde mest betydning for vor sag."

Dette var fuldkomment rigtigt; men når vi nu ser tilbage 
til A. D. Jørgensens person og gerning, er sorgen veget. Tilbage er det lyseste minde om en stærk dansk mand, en klog sønderjyde, der blev vor første historiker og sin fødebys stolthed.

Når A. D. Jørgensen fortalte eller skrev historie, kunde han brede en ejendommelig poesi over sine emner, mest og naturligst, hvor de stod hans hjerte nærmest. Så oplevede han, hvad han har skrevet om $i$ et overmåde smukt brev til den gamle Frederik B arfod, "glade, lykkelige timer, et arbejde $i$ lyst, en rig belønning $i$ den voksende forståelse af emnet, i enkelthedernes opdagelse og i samlingens overraskelse«. Eller som han i samme brev gentager fra bogen om Zoëga:

"Lønnen er dog større, end mange aner; den ligger ikke blot i selve arbejdet og glæden over dets frugter, men $i$ den rigdom af åndelige erfaringer, som det fører med sig, og den tankefylde, som det avler.»

I et tidligere brev til religionshistorikeren $\mathrm{Vodsk}$ ov skriver A. D. Jørgensen:

"Det, som har varigst betydning, er den simple vederhæftige fortælling af granskningens resultater, således som de interesserer én selv og derfor må forudsættes også at interessere andre. Fører fortællingen da med sig, at fortællerens sind beræges, da vil det let kunne høres på hans stemme og ordføring, og fremstiller der sig alt imens større syner og billeder for hans øje, da vil de let trænge sig frem, ind imellem de flittigt udarbejdede studier.«

Således var A. D. Jørgensens værk: flittigt udarbejdede studier, isprængt større syner og billeder, tit fremført med bevæget og altid med ædel stemme og ordføjning. Jeg vender tilbage til den fortælling, jeg allerede har nævnt, om Sæmund Frode og den hellige biskop Ion, om Sæmund, der indsugede al tidens visdom, så han glemte sit eget, om Ion, der førte ham hjem fra fremmed land, så han mere end nogen anden så værdien af $\sin$ hjemøs overleverede skatte, om de to mænd, der hver for sig så smukt i A. D. Jørgensens fremstilling genspejler to sider af hans tanke og hans egen åndelige udvikling. 
Om Sæmund Frode siger han: "Hans lærdom var ikke nogen gold skat, den kom tværtimod mange til gode; thi den havde dannet hans ånd, øvet hans tanke og beriget hans hjerte, så han forstod sig på alt, hvad der udkrævede omtanke og kløgt; han kunde finde udveje af enhver vanskelighed, former for ethvert forlig, han tog sig af ethvert arbejde, som havde krav på almindelig deltagelse«. Det er tydeligt, at A. D. Jorgensen onskede at ligne ham, og han lignede ham! Lige så smukt fortæller han om Sæmunds ungdomsven biskop Ion Øgmundsson.

Lad mig fremføre de ord, A. D. Jørgensen gengiver af Ion om hans lærer:

"Der siges, at han ikke kunde høre folk fremhæve nogen mand som særlig udmærket $i$ en eller anden retning uden at komme til at tænke på ham. "Islejf biskop, min lærer«, sagde han da, "han var den smukkeste af alle mænd, han var den klogeste og bedste«. Når man da indvendte, at talen slet ikke var om den salig biskop, så svarede han: "Men jeg må mindes ham, hver gang jeg hører tale om en udmærket mand; thi således var han«.»

Og således vil jeg i dag gerne mindes rigsarkivar A. D. Jørgensen i hans fødeby: som den klogeste og bedste. En af vort lands rigest udrustede mænd, stor $i$ gaver, $i$ arbejde, $i$ fædrelandskærlighed og i sindets varme. Vi er mange, der har grund til at tænke på ham med personlig taknemmelighed; der er grund for os alle til at samles om og ære hans minde. Vi kender ham som en af vore egne og nævner A. D. Jørgensen blandt dem, som $\mathrm{i}$ tunge tider aldrig mistvivlede om ror frelse. Vi vil søge at følge ham også i dette. 